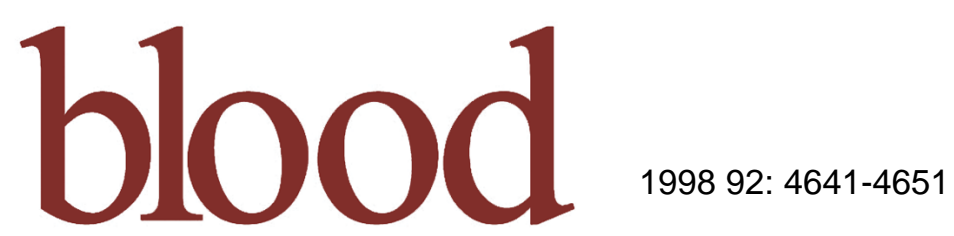

\title{
Structurally Specific Heparan Sulfates Support Primitive Human Hematopoiesis by Formation of a Multimolecular Stem Cell Niche
}

Pankaj Gupta, Theodore R. Oegema, Jr, Joseph J. Brazil, Arkadiusz Z. Dudek, Arne Slungaard and Catherine M. Verfaillie

Updated information and services can be found at:

http://bloodjournal.hematologylibrary.org/cgi/content/full/92/12/4641

Articles on similar topics may be found in the following Blood collections:

Hematopoiesis and Stem Cells (2715 articles)

Information about reproducing this article in parts or in its entirety may be found online at:

http://bloodjournal.hematologylibrary.org/misc/rights.dtl\#repub_requests

Information about ordering reprints may be found online at:

http://bloodjournal.hematologylibrary.org/misc/rights.dtl\#reprints

Information about subscriptions and ASH membership may be found online at:

http://bloodjournal.hematologylibrary.org/subscriptions/index.dtl

Blood (print ISSN 0006-4971, online ISSN 1528-0020), is published semimonthly by the American Society of Hematology, 1900 M St, NW, Suite 200, Washington DC 20036.

Copyright 2007 by The American Society of Hematology; all rights reserved.

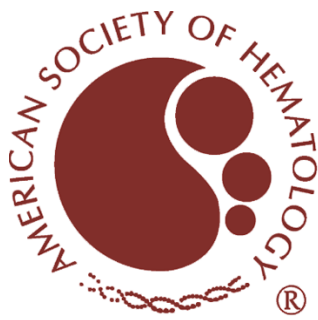




\title{
Structurally Specific Heparan Sulfates Support Primitive Human Hematopoiesis by Formation of a Multimolecular Stem Cell Niche
}

\author{
By Pankaj Gupta, Theodore R. Oegema J r, J oseph J . Brazil, Arkadiusz Z. Dudek, Arne Slungaard, \\ and Catherine M. Verfaillie
}

\begin{abstract}
Stem cell localization, conservation, and differentiation is believed to occur in niches in the marrow stromal microenvironment. Our recent observation that long-term in vitro human hematopoiesis requires a stromal heparan sulfate proteoglycan (HSPG) led us to hypothesize that such HSPG may orchestrate the formation of the stem cell niche. We compared the structure and function of HS from M2-10B4, a hematopoiesis-supportive cell line, with HS from a nonsupportive cell line, FHS-173-We. Long-term culture-initiating cell (LTC-IC) maintenance was enhanced by PG from supportive cells but not by PG from nonsupportive cells $(P<.005)$. The supportive HS were significantly larger and more highly sulfated than the nonsupportive HS. Specifically, supportive HS contained higher 6-0-sulfation on the glucosamine residues. In agreement with these obsenvations, purified 6-0sulfated heparin and highly 6-0-sulfated bovine kidney HS similarly maintained LTC-IC. In contrast, completely desulfated heparin, N-sulfated heparin, and unmodified heparin did not support LTC-IC maintenance. Moreover, the supportive HS promoted LTC-IC maintenance but not differentiation of CD34 ${ }^{+} / \mathrm{HLA}^{-D R^{-}}$cells into colony-forming cells (CFCs) and
\end{abstract}

$\mathbf{T}$ HE REGULATED proliferation, commitment, and terminal differentiation of undifferentiated hematopoietic stem cells (HSCs) occurs in intimate contact with the bone marrow (BM) microenvironment. This results in preservation of the stem cell pool while permitting controlled cell proliferation and differentiation. ${ }^{1-5}$ Stem cells are thought to be localized in stem cell niches or local area networks in the microenvironment, where they interact with the components of their nicheincluding stromal cells, extracellular matrix (ECM) proteins, and cytokines that are present on stromal cells or bound to ECM macromolecules. Regional variation in these components within the hematopoietic microenvironment may create niches that are specific for cells at a given stage of differentiation. ${ }^{6,7}$ Specific niches might exist that induce conservation and maintenance of primitive progenitors and other niches that promote proliferation and differentiation, depending on the specific cytokines and matrix components present within it. At present, the identity and structural characteristics of the macromolecules that mediate the formation of such niches remain unknown.

Stromal cell lines that differ in their hematopoietic supportive capability (reviewed in Deryugina and Müller-Sieburg ${ }^{6}$ ) may represent niches containing specific components critical for either survival, proliferation, or differentiation of stem cells. ${ }^{8}$ To define components of niches that support maintenance of primitive human hematopoietic progenitors, we initiated studies to identify and compare the factors produced by hematopoiesissupportive and nonsupportive cells. We have previously demonstrated that $50 \%$ of human long-term culture-initiating cells (LTC-ICs) can be maintained for 5 to 8 weeks in vitro when cultured in medium conditioned by human mixed cell type marrow stromal feeders or by the murine BM stroma-derived fibroblast cell line M2-10B4 (the supportive cells). ${ }^{9-11}$ Furthermore, $100 \%$ of LTC-ICs are maintained for 8 weeks in stroma-conditioned medium supplemented with the heparin- mature blood cells. The supportive HS but not the nonsupportive HS bound both cytokines and matrix components critical for hematopoiesis, including interleukin-3 (IL-3), macrophage inflammatory protein-1 $\alpha$ (MIP-1 $\alpha$ ), and thrombospondin (TSP). Significantly more $\mathrm{CD}^{+}{ }^{+}$cells adhered directly to immobilized O-sulfated heparin than to $\mathrm{N}$-sulfated or desulfated heparin. Thus, hematopoiesis-supportive stromal HSPG possessing large, highly 6-0-sulfated HS mediate the juxtaposition of hematopoietic progenitors with stromal cells, specific growth-promoting (IL-3) and growth-inhibitory (MIP-1 $\alpha$ and platelet factor 4 [PF4]) cytokines, and extracellular matrix (ECM) proteins such as TSP. We conclude that the structural specificity of stromal HSPG that detemines the selective colocalization of cytokines and ECM components leads to the formation of discrete niches, thereby orchestrating the controlled growth and differentiation of stem cells. These findings may have important implications for ex vivo expansion of and gene transfer into primitive hematopoietic progenitors.

(C) 1998 by The American Society of Hematology.

binding cytokines interleukin-3 (IL-3) + macrophage inflammatory protein- $1 \alpha(\mathrm{MIP}-1 \alpha)^{11}$ or IL-3 + platelet factor 4 (PF4). ${ }^{12}$ Interestingly, even though cytokine levels in medium conditioned by the human embryonic cell line FHS-173-We (the nonsupportive cells) are similar to marrow stromal supernatant $(\mathrm{SN}),{ }^{13-16}$ conditioned medium from this cell line maintains only $10 \%$ of LTC-ICs for 5 weeks. ${ }^{13}$ Thus, microenvironmental factors other than cytokines appear to be responsible for differences in LTC-IC supportive capability of these two cell lines.

We have shown that one such microenvironmental factor essential for maintenance of human LTC-ICs is a heparan

From the Departments of Medicine, Biochemistry, and Orthopadic Surgery, VA Medical Center and University of Minnesota Medical School, Minneapolis, MN.

Submitted December 31, 1997; accepted August 12, 1998.

Supported by the US Department of Veterans Affairs; National Institutes of Health Grants No. R01-HL-48738, P01-CA-65493, and AR-32372; the Minnesota Medical Foundation; the University of Minnesota Bone Marrow Transplant Research Fund; American Heart Association Grant-in-Aid No. 94012990; and the University of Minnesota Hospital and Clinic. C.M.V. is a Scholar of the Leukemia Society of America.

Address reprint requests to Pankaj Gupta, MD, Hematology/ Oncology Section, VA Medical Center, One Veterans Drive, Minneapolis, MN 55417, e-mail: gupta013@gold.tc.umn.edu; or Catherine M. Verfaillie, MD, Department of Medicine, Box 806 UMHC, 420 Delaware St SE, Minneapolis, MN 55455, e-mail: verfa001@maroon. tc.umn.edu.

The publication costs of this article were defrayed in part by page charge payment. This article must therefore be hereby marked "advertisement" in accordance with 18 U.S.C. section 1734 solely to indicate this fact.

(C) 1998 by The American Society of Hematology.

0006-4971/98/9212-0010\$3.00/0 
sulfate proteoglycan (HSPG) secreted into the $\mathrm{SN}$ of the supportive cells. ${ }^{17}$ HSPGs are a ubiquitous component of all tissue microenvironments, including the BM microenvironment, ${ }^{18-21}$ and are present both on cell surfaces and in the ECM. They can mediate cell adhesion, bind and modulate the activity of cytokines, and also bind diverse ECM proteins. ${ }^{22}$ HSPGs at least partly mediate adhesion of hematopoietic progenitors to stromal cells..$^{7,23-25}$ Furthermore, a number of hematopoietic cytokines, such as IL-3, granulocyte-macrophage colonystimulating factor (GM-CSF), basic fibroblast growth factor (bFGF), and hepatocyte growth factor (HGF), bind to HS. 4,5,26,27 They may therefore form the backbone of macromolecular complexes in the microenvironment that regulate cell growth and differentiation. . $^{18,22,28-31}$

Structurally, HSPGs are highly heterogeneous macromolecules composed of a core protein and covalently linked, sulfated HS side chains. These HS glycosaminoglycans (GAGs) consist of repeating disaccharide units of D-glucosamine $(\mathrm{GlcN})$ and a hexuronic acid (UA) that is either D-glucuronic acid (GlcA) or L-iduronic acid (IdoA). HSPGs from different tissues of origin have unique structural characteristics due to differences in their core proteins as well as in the nature, number, and pattern of sulfation of the disaccharides, including variability in $\mathrm{N}-$, 6-O-, and, rarely, 3-O-sulfation of GlcN, 2-O-sulfation of IdoA, and sometimes 2-O-sulfation of GlcA. ${ }^{32}$ It is believed that these differences are responsible for highly specific interactions of GAGs with diverse macromolecules. ${ }^{32,33}$

Specificity in the pattern of O-sulfation of HS is one of the important determinants of its functional specificity and its ability to bind cytokines and to modulate cell proliferation and differentiation. ${ }^{26,27,34-38}$ Bovine kidney HS has a high degree of 6-O-sulfation of the first $\mathrm{N}$-acetylated glucosamine adjacent to the terminal $\mathrm{N}$-sulfated glucosamine at the interfaces between sulfated and nonsulfated blocks. ${ }^{39}$ We have recently shown that this HS supports LTC-IC maintenance. ${ }^{17}$

We hypothesized that (1) differences in HS secreted by the hematopoiesis-supportive and nonsupportive cells may be responsible for the observed differences in LTC-IC maintenance by these two cell lines and (2) the hematopoiesis-supportive activity of these HS may depend on specific patterns of sulfation that allow colocalization of HSC with cytokines and ECM components that support the conservation and proliferation of HSC. Such HSPGs would thus form the backbone of a functional stem cell niche. In this report, we describe the structural and functional characteristics of heparan sulfate required to form a functional microenvironment that supports long-term in vitro human hematopoiesis.

\section{MATERIALS AND METHODS}

\section{Stromal Feeders and Cell Line Cultures}

Long-term bone marrow culture (LTBMC) medium consisted of Iscove's modified Dulbecco's medium (IMDM) with $12.5 \%$ fetal calf serum (FCS), $12.5 \%$ horse serum, $2 \mathrm{mmol} / \mathrm{L}$ L-glutamine, 1,000 U/mL penicillin, $100 \mathrm{U} / \mathrm{mL}$ streptomycin, and $10^{-6} \mathrm{~mol} / \mathrm{L}$ hydrocortisone. ${ }^{40}$ The M2-10B4 cell line (a kind gift from Dr C.J. Eaves, Terry Fox Laboratories, Vancouver, British Columbia, Canada) was maintained by passage in RPMI-1640 medium $+10 \%$ FCS and the FHS-173-We cell line (from ATCC, Rockville, MD) in Dulbecco's modified Eagle's medium (DMEM) $+10 \%$ FCS. When confluent, cells were irradiated at
6,000 rads and subsequently maintained in LTBMC medium. Human stromal feeders were established from human BM mononuclear cells as previously described, irradiated at 1,250 rads when confluent, and maintained in LTBMC medium. ${ }^{40}$ Supernatants from irradiated cultures of human stroma or cell lines were harvested 2 to 3 days after a half-medium change, centrifuged to remove cell debris, and frozen at $-70^{\circ} \mathrm{C}$ until use.

\section{Long-Term Cultures}

Cell separation. BM was aspirated in preservative-free heparin from the posterior iliac crest of healthy young volunteers after obtaining informed consent. BM mononuclear cells were separated by FicollHypaque centrifugation (specific gravity, 1.077) and enriched for $\mathrm{CD}^{+}{ }^{+}$cells using Ceprate LC CD34-avidin immunoadsorption columns (CellPro Inc, Bothell, WA). ${ }^{41}$ The CD $34^{+}$enriched cell population was labeled with anti-CD34-phycoerythrin (PE) and anti-HLA-DRfluorescein isothiocyanate (FITC) antibodies (Becton Dickinson, San Jose, CA) and CD34 ${ }^{+} / \mathrm{HLA}_{-} \mathrm{DR}^{-}$cells selected on a FACStar Plus flow cytometry system equipped with a Consort 32 computer. ${ }^{9,40}$

Cytokines and glycosaminoglycans. Recombinant human cytokines used in long-term cultures included granulocyte colony-stimulating factor (G-CSF; Neupogen; Amgen, Thousand Oaks, CA), GM-CSF (Immunex Corp, Seattle, WA), stem cell factor (SCF; a kind gift from Amgen), leukemia inhibitory factor (LIF; R \& D Systems Inc, Minneapolis, MN), MIP-1 $\alpha$ (R\&D Systems), and IL-6 (a kind gift from Dr G. Wong, Genetics Institute, Cambridge, MA). Bovine kidney HS and heparin were from Sigma (St Louis, MO), and the differentially chemically desulfated heparins were from Seikagaku America (Rockville, MD).

Culture system. $\mathrm{DR}^{-}$cells were suspended in a Transwell insert with a microporous $0.4-\mu \mathrm{m}$ membrane placed in stroma-free wells of 24-well plates. Media in the lower well were replaced 5 times weekly with $0.8 \mathrm{~mL}$ fresh unconditioned LTBMC medium, LTBMC medium supplemented with cytokines alone or in combination with cell linederived PGs (see below for method of purification), bovine kidney HS, and differentially sulfated heparin GAGs or with $\mathrm{SN}$ from stromal feeders. Cultures were maintained for 5 weeks at $37^{\circ} \mathrm{C}$ in humidified $5 \%$ $\mathrm{CO}_{2}$ atmosphere. The progeny of $\mathrm{DR}^{-}$cells recovered by vigorous washing were plated at limiting dilutions (22 replicates per concentration) onto irradiated M2-10B4 feeders in 96-well plates to enumerate LTC-ICs as described. ${ }^{9}$ The absolute number of LTC-IC was calculated using Poisson statistics. ${ }^{9,42}$

\section{Structural Analysis of Proteoglycans}

Purification of PGs from SN of supportive and nonsupportive cells. For use in long-term cultures, PGs in the $\mathrm{SN}$ of irradiated supportive and nonsupportive cells were radiolabeled ( 1 of 10 flasks were labeled) on the sulfate groups by addition of $50 \mu \mathrm{Ci} / \mathrm{mL} \mathrm{Na}{ }_{2}^{35} \mathrm{SO}_{4}$ (ICN Biomedicals Inc, Irvine, CA) in sulfate-replete (sulfate content of IMDM, $0.8 \mathrm{mmol} / \mathrm{L}$ ) LTBMC medium for 24 hours. PGs were purified by diethyl aminoethyl (DEAE)-Sephacel anion exchange highperformance liquid chromatography (HPLC; Beckman, Fullerton, CA), as previously described. ${ }^{17}$ For structural analysis, PGs were labeled with $20 \mu \mathrm{Ci} / \mathrm{mL}^{3} \mathrm{H}$-glucosamine (to label the GAG backbone; DuPont NEN, Boston, MA) and $50 \mu \mathrm{Ci} / \mathrm{mL} \mathrm{Na}_{2}{ }^{35} \mathrm{SO}_{4}$ in LTBMC medium for 18 to 24 hours, before purification by anion exchange HPLC.

Preparation of HSPGs. Purified, ${ }^{3} \mathrm{H}$ - and ${ }^{35} \mathrm{~S}$-labeled $\mathrm{PG}$ were digested by chondroitinase $\mathrm{ABC}$ (cABC; Seikagaku) and chromatographed on a Sephadex G-50 (Sigma) column, and undigested HSPGs eluting at $\mathrm{V}_{0}$ were collected. Free HS chains were released from the core protein by treatment of the HSPG with sodium hydroxide in the presence of sodium borohydride $\left(\mathrm{NaBH}_{4}\right)$. Between $96 \%$ and $99 \%$ of the purified HS from the various peaks was digestible by nitrous acid, ${ }^{43,44}$ indicating that this material was highly purified for HS. The 
size of the HSPG and HS was estimated by gel filtration chromatography on a $0.75 \times 95 \mathrm{~cm}$ Sepharose CL-6B column equilibrated in 4 $\mathrm{mol} / \mathrm{L}$ guanidine hydrochloride and $0.05 \mathrm{~mol} / \mathrm{L}$ sodium acetate, $\mathrm{pH} 5.8$. The approximate sizes of PG and GAG were estimated by the methods of Heinegard and Hascall ${ }^{45}$ and Wasteson, ${ }^{46}$ respectively.

Distribution of $\mathrm{N}$-sulfation and $\mathrm{O}$-sulfation in $\mathrm{HS} .{ }^{35} \mathrm{~S}$-and ${ }^{3} \mathrm{H}-\mathrm{la}-$ beled $\mathrm{HS}$ from both cells were subjected to low $\mathrm{pH}$ nitrous acid ( $\mathrm{pH} 1.5)$ deaminative cleavage of $\mathrm{N}$-sulfated regions as described. ${ }^{44}$ The digested oligosaccharides were resolved by gel filtration chromatography on a $0.75 \times 110 \mathrm{~cm}$ Sephadex G-25 column equilibrated and eluted at a rate of $6 \mathrm{~mL} / \mathrm{h}$ with $0.2 \mathrm{~mol} / \mathrm{L}$ ammonium acetate, $\mathrm{pH} 7.0 ; 0.3-\mathrm{mL}$ fractions were collected. The resulting oligosaccharides were analyzed as described previously. ${ }^{47}$

CarboPac PA1 chromatography. ${ }^{3} \mathrm{H}$ - and ${ }^{35} \mathrm{~S}$-labeled CS/DS PGs in the $\mathrm{SN}$ of the two cells were recovered from DEAE-Sephacel anion exchange HPLC, dialyzed against water, and lyophilized. Analysis of sulfated disaccharides was performed as described. ${ }^{48}$ Briefly, CS/DS were digested using $\mathrm{CABC}$, the resulting disaccharides were reduced by a modified borohydride reduction reaction to stabilize unsaturated disaccharides to alkali, and the reduced alditols were desalted using Dowex 50 hydrogen. The disaccharides were resolved by HPLC using a CarboPac PA1 column eluted at $1 \mathrm{~mL} / \mathrm{min}$ with a sodium trifluoroacetic acid gradient in $0.1 \mathrm{~mol} / \mathrm{L} \mathrm{NaOH}$. Fractions of $1 \mathrm{~mL}$ were collected. Disaccharides were detected by integrated pulse amperometry on a pulsed electrochemical detector module and identified by comparison to known disaccharide standards. The ${ }^{3} \mathrm{H}$ and ${ }^{35} \mathrm{~S}$ radioactivity incorporated in the disaccharides was measured, and the relative metabolism of ${ }^{3} \mathrm{H}$-glucosamine by the 2 cells was estimated by the ratio of ${ }^{3} \mathrm{H}:{ }^{35} \mathrm{~S}$ in the sulfated disaccharide peaks. ${ }^{48}$

\section{2-O-Desulfation of GAGs}

Unmodified heparin or O-sulfated heparin was dissolved in $\mathrm{dH}_{2} \mathrm{O}(4$ $\mathrm{mg} / \mathrm{mL}$ ) and the $\mathrm{pH}$ was adjusted to 12.5 using $0.1 \mathrm{~N} \mathrm{NaOH} .{ }^{49}$ The solution was frozen, lyophilized, and then rehydrated in the original volume of $\mathrm{dH}_{2} \mathrm{O}$ and dialyzed against water.

\section{Iodination of $H S$}

Purified HS from the two cells was labeled with tyramine ${ }^{50,51}$ and iodinated using carrier-free $\mathrm{Na}_{2}{ }^{125}$ I (Amersham, Arlington Heights, IL) and the Iodo-gen iodination reagent (Pierce, Rockford, IL) ${ }^{51}$ Free ${ }^{125} \mathrm{I}$ was removed from the labeled HS by separation on a Sephadex G-25 column, followed by exhaustive dialysis. The specific activity was 3.4 $\mu \mathrm{Ci} / \mu \mathrm{g}$ for the iodinated supportive $\mathrm{HS}$ and $7.2 \mu \mathrm{Ci} / \mu \mathrm{g}$ for the nonsupportive HS.

\section{Affinity Coelectrophoresis (ACE)}

Binding of ${ }^{35} \mathrm{~S}$-labeled HS from the supportive and nonsupportive cells to cytokines including IL-3 (R \& D Systems), PF4, MIP-1 $\alpha$, and bFGF (R \& D Systems) and to ECM molecules including thrombospondin (TSP; a kind gift from Dr Robert Hebbel, University of Minnesota, Minneapolis, MN) and fibronectin (FN; Sigma) was examined using ACE. To digest residual core proteins of the HSPGs and any other remaining proteins before ACE, ${ }^{3} \mathrm{H}$ - and ${ }^{35} \mathrm{~S}$-labeled HS preparations obtained from the two cells as described above were further incubated with proteinase $\mathrm{K}$ (Sigma) followed by heating at $100^{\circ} \mathrm{C}$ for 1 minute to inactivate the enzyme. ACE was performed as described. ${ }^{52}$ Briefly, a $1 \%$ agarose gel (low melting point Seaplaque; FMC, Rockland, MD) in 50 $\mathrm{mmol} / \mathrm{L}$ sodium MOPSO (Sigma), $\mathrm{pH} 7.0,125 \mathrm{mmol} / \mathrm{L} \mathrm{NaCl}, 0.5 \%$ CHAPS buffer was cast with a strip well (for HS) and a perpendicular 8-lane comb (for proteins). Protein samples prepared at twice the desired concentration in MOPSO/NaCl/CHAPS electrophoresis buffer were mixed with an equal volume of $2 \%$ agarose and allowed to gel in appropriate wells created by the 8-lane comb. The HS preparation in MOPSO/NaCl/CHAPS electrophoresis buffer containing bromophenol blue and sucrose was added to the strip well. Electrophoresis was performed in a Hoefer electrophoresis apparatus in MOPSO/NaCl running buffer prepared without CHAPS at $330 \mathrm{~mA}, 45$ to $60 \mathrm{~V}$ for 2.5 to 2.75 hours at $20^{\circ} \mathrm{C}$ to $25^{\circ} \mathrm{C}$. Gels were air-dried, submerged in Amplify solution (Amersham, Arlington Heights, IL), redried, and autoradiographed at $-80^{\circ} \mathrm{C}$ on Kodak Biomax MS film using a Kodak Biomax TranScreen LE intensifying screen (Eastman Kodak, Rochester, NY). In other experiments, the binding of ${ }^{125}$ I-labeled cell line HS to TSP and MIP- $1 \alpha$ was examined by ACE.

\section{Surface Plasmon Resonance (SPR)}

The binding of GAGs to PF4 was examined on BIAcore biosensor equipment (Pharmacia, Uppsala, Sweden) using surface plasmon resonance, which is highly sensitive and monitors real-time binding of an analyte (GAG) to a ligand (PF4) immobilized on a sensor chip. ${ }^{53,54} \mathrm{~A}$ change in mass at the surface of the chip upon binding of the analyte causes a change in refractive index, changing the angle at which plasmon resonance occurs. This is measured in resonance units (RU), which correlate with the amount of analyte bound $\left(1 \mathrm{RU}=1 \mathrm{pg} / \mathrm{mm}^{2}\right)$. For assessment of binding of GAG in solution to immobilized PF4, 1 $\mu \mathrm{g} / \mathrm{mL}$ biotinylated PF4 in HEPES buffer containing $150 \mathrm{mmol} / \mathrm{L} \mathrm{NaCl}$, $1 \mathrm{mmol} / \mathrm{L} \mathrm{CaCl}_{2}$, and $1 \mathrm{mmol} / \mathrm{L} \mathrm{MgCl}_{2}$ was perfused over an SA5 (with immobilized streptavidin) sensor chip. GAGs in equilibration buffer (HEPES buffer as above with $0.005 \%$ surfactant p20) in a range of concentrations between $10^{-4}$ and $10^{-7} \mathrm{~mol} / \mathrm{L}$ were perfused over the chip at $20 \mu \mathrm{L} / \mathrm{min}$. The $\mathrm{K}_{\mathrm{D}}$ was calculated using BIAevaluation 2.1 software (Pharmacia Biosensor AB, Uppsala, Sweden) from the average of $\mathrm{k}_{\mathrm{a}}$ (association or run-on phase) and $\mathrm{k}_{\mathrm{d}}$ (dissociation or wash-out phase) kinetics: $K_{D}=k_{d} / k_{a}$ (where $k_{a}$ is derived from the $k_{s}$ plot).

\section{Adhesion of $\mathrm{CD} 34^{+}$Cells}

Unmodified or differentially sulfated heparins were conjugated to ovalbumin by amide linkage, using 1-ethyl-3-(3-dimethylaminopropyl)carbodiimide (EDC). ${ }^{55}$ Briefly, GAG and ovalbumin were dissolved (2 $\mathrm{mg}$ each) in $1 \mathrm{~mL}$ distilled water and $20 \mathrm{mg}$ of EDC in $50 \mu \mathrm{L}$ water was added (all chemicals from Sigma). The mixture was shaken at $4^{\circ} \mathrm{C}$ for 12 hours to couple GAGs to ovalbumin. EDC was removed by dialysis against phosphate-buffered saline (PBS). For adhesion experiments, 48 -well plates were coated by overnight incubation at $37^{\circ} \mathrm{C}$ with 150 $\mu \mathrm{L} /$ well of $5 \%$ fatty acid free bovine serum albumin (BSA; Sigma) or $100 \mu \mathrm{g} / \mathrm{mL}$ ovalbumin-conjugated GAGs in Voller's bicarbonate buffer. For some experiments, plates were incubated for an additional 24 hours at $4^{\circ} \mathrm{C}$. Wells were washed and blocked with $1 \%$ BSA in PBS before the adhesion assay. Fluorescence-activated cell sorting (FACS)-sorted $\mathrm{CD} 34^{+}$cells were labeled with ${ }^{51} \mathrm{Cr}$ and resuspended in IMDM $+0.3 \%$ BSA, and 20,000 cells in $250 \mu \mathrm{L}$ volume/well were allowed to adhere to the coated wells for 4 hours at $37^{\circ} \mathrm{C}$. The total radioactivity present in an equivalent number of cells $(20,000$ cells in $250 \mu \mathrm{L}$ volume $)$ was measured separately. Nonadherent cells were removed by four to six gentle washings with PBS, and their removal was confirmed by visual inspection. Adherent cells were lysed by addition of $500 \mu \mathrm{L} /$ well of $1 \%$ Triton $\mathrm{X}-100$ in $\mathrm{PBS}$ and ${ }^{51} \mathrm{Cr}$ radioactivity was measured. The percentage of adhesion was calculated as: $\%$ adhesion $=\mathrm{cpm}$ in adherent cell lysate $\times 100 /$ total cpm in 20,000 cells plated.

\section{Binding of ${ }^{125} \mathrm{I}-\mathrm{HS}$ to $\mathrm{CD} 34^{+}$Cells}

$\mathrm{CD}^{+} 4^{+}$cells were suspended in $0.5 \mathrm{~mL}$ cold IMDM $+0.3 \%$ BSA, and ${ }^{125}$ I-HS from the supportive or nonsupportive cells was added. After incubation on ice with gentle mixing for 90 minutes (maximal binding was seen at 60 to 90 minutes in preliminary experiments; data not shown), the cells were washed with cold IMDM $+0.3 \%$ BSA and the bound radioactivity in the cell pellet counted using a gamma counter. 


\section{Statistics}

Results of data are reported as the mean \pm SEM. Levels of significance were determined by the two-sided Student's $t$-test.

\section{RESULTS}

PGs from Hematopoiesis-Supportive Cells But Not From Nonsupportive Cells Support LTC-IC Maintenance

Proteoglycans purified from the SN of the two cells were evaluated for their ability to support LTC-IC maintenance. A combination of supportive cell PGs and the picogram concentrations of cytokines found in stromal SN supported maintenance of the same number of LTC-IC as cultures fed with unfractionated stromal SN. However, supportive cell PG alone or cytokines alone were unable to maintain LTC-IC (Fig 1). In contrast, when purified PGs from the $\mathrm{SN}$ of the nonsupportive cells were combined with the same cytokines, no increase in LTC-IC maintenance was seen over that with cytokines alone. Maintenance of LTC-IC in cultures supplemented with nonsupportive cell PGs + cytokines or with supportive cell PGs + cytokines in the present study was comparable to the LTC-IC maintenance observed in the presence of unfractionated nonsupportive cell SN and supportive cell SN previously described by our group. ${ }^{13}$ This indicates that a combination of cytokines at concentrations found in stromal SN + purified PGs recreates the hematopoiesissupportive capabilities of unfractionated SN from the two cell lines.

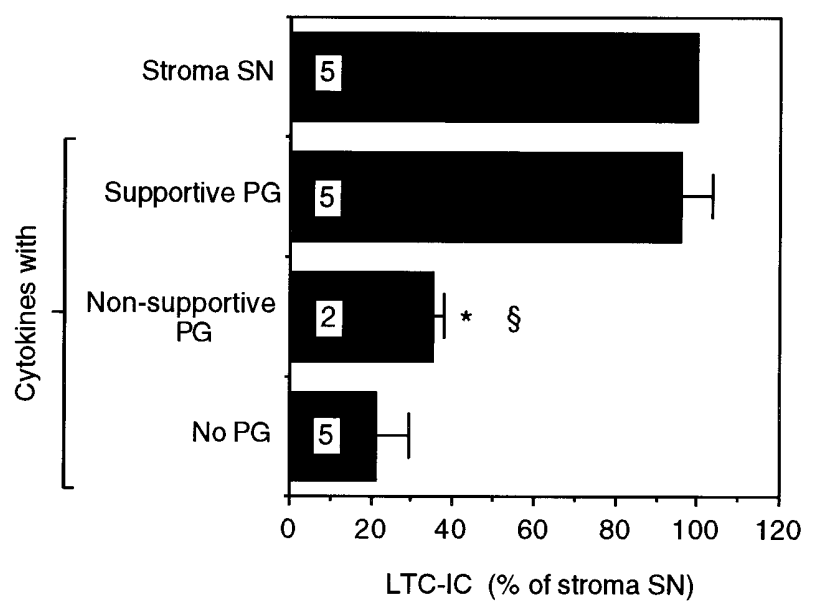

Fig 1. LTC-IC supportive capability of proteoglycans from the SN of the supportive and nonsupportive cells. A total of 14,000 to 17,000 DR- $^{-}$cells were plated in 0.4- $\mu \mathrm{m}$ transwell inserts in 24-well tissue culture clusters. Cultures were maintained by daily replacement of the medium in the lower chambers of the wells by either stroma supematant (Stroma SN) or by LTBMC medium supplemented with a combination of cytokines (500 pg/ $\mathrm{mL}$ G-CSF, $50 \mathrm{pg} / \mathrm{mL}$ GM-CSF, 200 $\mathrm{pg} / \mathrm{mL}$ SCF, $50 \mathrm{pg} / \mathrm{mL}$ LIF, $2 \mathrm{ng} / \mathrm{mL}$ IL-6, and $200 \mathrm{pg} / \mathrm{mL} \mathrm{MIP}-1 \alpha$ ) with or without proteoglycans from the $\mathrm{SN}$ of the supportive or nonsupportive cells. Cultures were harvested after 5 weeks and cells were replated at limiting dilutions for estimation of LTC-IC frequency. The absolute number of LTC-IC in the starting cell population at day 0 was $0.67 \pm 0.01$ per $100 \mathrm{DR}^{-}$cells plated. The absolute number of LTC-IC after 5 weeks of culture in stroma SN was $0.32 \pm 0.03$ per $100 \mathrm{DR}^{-}$ cells initially plated at day 0 ( $48 \%$ of day 0 LTC-IC). Numbers within bars indicate number of experiments. Comparison between Stroma SN and other conditions: $* P<.001$. Comparison between the supportive cells and other conditions: $\S P<.005$.
Supportive HS Are Larger and More 6-O-Sulfated

Than Nonsupportive $H S$

Because the LTC-IC maintaining activity of the supportive PGs is due to their $\mathrm{HS},{ }^{17}$ we examined the differences in HS from the supportive and the nonsupportive cells. Upon anion exchange HPLC, ${ }^{35} \mathrm{SO}_{4}$ - and ${ }^{3} \mathrm{H}$-glucosamine-labeled PG from $\mathrm{SN}$ of the supportive cells eluted as a single major peak, whereas PGs from the nonsupportive cells eluted in three peaks (labeled A, B, and C; data not shown). The three peaks in PGs from the nonsupportive cells and comparable regions from the supportive cells' PGs were analyzed separately.

HS from both cells eluted largely in peak A, with a small proportion of HS in peak B from the nonsupportive cells. In three independent experiments, the percentage of HS in peak A of PGs from the nonsupportive cells was $89 \% \pm 3 \%$, in peak B was $19 \% \pm 11 \%$, and in the supportive cell PG peak A was $33 \% \pm 8 \%$. The rest of the GAGs in these peaks, and almost all the GAGs in peak $\mathrm{C}$, were CS/DS. The overall proportion of HSPG in nonsupportive cell PGs $(41 \%)$ was higher than in supportive cell PGs (13\%), and total ${ }^{35} \mathrm{SO}_{4}$ and ${ }^{3} \mathrm{H}$-glucosamine in HSPG from the nonsupportive cells was greater than in HSPG from the supportive cells. Therefore, structural rather than the quantitative differences in HS from the two cells must be responsible for the observed difference in LTC-IC maintenance.

Size of HPSGs and GAGs. The size of HSPGs from the two cells was similar (average molecular weight $\left[\mathrm{M}_{\mathrm{r}}\right], 160$ to 210 $\mathrm{kD})$. However, the average size of supportive HS (45 kD) was larger than nonsupportive HS (both peak A [22 kD], which contains the majority of its HS, and peak B [33 kD], which constitutes a smaller proportion of its HS).

Degree of sulfation of $H S$. Sulfation, determined as the ratio of dpm of ${ }^{35} \mathrm{~S}$-sulfate to ${ }^{3} \mathrm{H}$-glucosamine, was higher in $\mathrm{PGs}$ from the supportive cells than from the nonsupportive cells in three independent experiments. Because different cell types can have different glucosamine pool sizes and fluxes, the specific activity of the sulfated disaccharides generated by cABC was used to correct the measured incorporation of ${ }^{3} \mathrm{H}$-glucosamine in GAGs by the supportive cells and the nonsupportive cells, as outlined by Midura et al. ${ }^{48}$ The average ratio of ${ }^{3} \mathrm{H}:{ }^{35} \mathrm{~S}$ in the sulfated disaccharides $(\Delta \mathrm{Di}-4 \mathrm{~S}$ and $\Delta \mathrm{Di}-6 \mathrm{~S})$ was 1.60 for the nonsupportive cells and 0.66 for the supportive cells. This indicates that the nonsupportive cells incorporate more radiolabeled glucosamine into identical sulfated disaccharides than the supportive cells. However, even after correction for this difference in ${ }^{3} \mathrm{H}$-glucosamine incorporation, the ${ }^{35} \mathrm{SO}_{4}$ to ${ }^{3} \mathrm{H}$-glucosamine ratio was higher in the supportive cell's proteoglycans, HSPGs, and HS than in the nonsupportive cells (the ${ }^{35} \mathrm{~S}:{ }^{3} \mathrm{H}$ ratio was 1.11 in supportive HS and 0.43 in nonsupportive HS).

These results were consistent with elution from DEAESephacel. Nonsupportive HS eluted at lower $\mathrm{NaCl}$ concentrations than supportive HS. This indicates that differences in elution of HSPGs are due to differences in sulfation of their HS rather than to differences in the number of HS chains per molecule of core protein. Nonsupportive HS eluted at 0.39 $\mathrm{mol} / \mathrm{L} \mathrm{NaCl}$ (peak A) and at $0.42 \mathrm{~mol} / \mathrm{L} \mathrm{NaCl}$ (peak B). The supportive HS eluted as a major peak at $0.48 \mathrm{~mol} / \mathrm{L}$, with minor peaks at 0.37 and $0.43 \mathrm{~mol} / \mathrm{L}$. Thus, a second difference in HS 
from the two cells is the higher proportion of more highly sulfated HS secreted by the supportive cells compared with HS from the nonsupportive cells.

Sulfation pattern of $H S$. To determine if supportive and nonsupportive $\mathrm{HS}$ differ in sulfation pattern, we digested ${ }^{3} \mathrm{H}$-glucosamine- and ${ }^{35} \mathrm{SO}_{4}$-labeled $\mathrm{HS}$ with low $\mathrm{pH}$ nitrous acid. The resulting oligosaccharides were resolved by Sephadex G-25 column chromatography. At low $\mathrm{pH}$, nitrous acid cleaves $\mathrm{HS}$ at $\mathrm{GlcNSO}_{3}$ residues, leaving regions with GlcNAc as intact oligosaccharides. ${ }^{44}$ When the resulting oligosaccharides and disaccharides are resolved by G-25 gel filtration chromatography, ${ }^{47}$ large undigested oligosaccharides $(>8$ monosaccharide residues) containing contiguous GlcNAc residues elute in the excluded volume (pool I in Fig 2), disaccharides and free sulfate derived from regions containing contiguous $\mathrm{GlcNSO}_{3}$ residues elute in the total volume (pool III), and oligosaccharides of 3-8 monosaccharides derived from cleavage of alternating [-(UA$\mathrm{GlcNSO}_{3}$-UA-GlcNAc) $\left.)_{n^{-}}\right]$or variably spaced regions containing both GlcNAc and $\mathrm{GlcNSO}_{3}$ residues elute in the included volume (pool II; fractions between vertical bars). The ${ }^{3} \mathrm{H}$-glucosamine in pool II is indicative of the proportion of the total carbohydrate backbone contained in such oligosaccharides. The ${ }^{35} \mathrm{~S}$ in pool II oligosaccharides is largely as 6-O-sulfated GlcN, rather than as 2-O-sulfated UA, ${ }^{39,47}$ and is therefore representative of the extent of 6-O-sulfation on GlcNAc residues adjacent to the terminal $\mathrm{GlcNSO}_{3}$ residue. . $^{39,56}$

As shown in Fig 2, the proportion of the total carbohydrate in these oligosaccharides was equivalent in nonsupportive HS $\left(41 \%{ }^{3} \mathrm{H}\right.$ in peak A) and the supportive $\mathrm{HS}\left(40 \%{ }^{3} \mathrm{H}\right.$ in peak $\left.\mathrm{A}\right)$. However, in two independent experiments, the proportion of ${ }^{35} \mathrm{~S}$ in pool II from supportive HS (27\%) was 1.7- to 1.8-fold greater than in nonsupportive HS ( $15 \%$ to $16 \%$ ). Moreover, even after correction for differential ${ }^{3} \mathrm{H}$-glucosamine incorporation by the two cells (see above), the sulfate:carbohydrate backbone ratio $\left({ }^{35} \mathrm{~S}:{ }^{3} \mathrm{H}\right)$ in the supportive cell oligosaccharides $(0.63: 1)$ was higher than that in the nonsupportive cell peak A $(0.26: 1)$ or in the nonsupportive cell peak B oligosaccharides $(0.43: 1)$. Our results therefore support the conclusion that the observed differences in percent sulfation in pool II in the two HS are largely a result of a higher degree of 6-O-sulfation of the terminal GlcN residues in supportive $\mathrm{HS}$ than in nonsupportive HS. Thus, supportive HS are more 6-O-sulfated than nonsupportive HS.

\section{6-O-Sulfation Is Essential for the LTC-IC Maintaining Capability of GAGs}

We next examined if these differences in sulfation patterns have functional implications for the ability of GAGs to support LTC-IC. We evaluated the ability of chemically modified heparins, which are selectively desulfated at one or more positions, to maintain LTC-IC. A combination of unmodified heparin and cytokines did not significantly increase LTC-IC maintenance over that seen with cytokines alone (Fig 3A). This suggested that the common, highly $\mathrm{N}$ - and $\mathrm{O}$-sulfated heparin motif [-IdoA $\left.\left(2-\mathrm{OSO}_{3}\right)-\mathrm{GlcNSO}_{3}\left(6-\mathrm{OSO}_{3}\right)-\right]$ may not be optimal for LTC-IC maintenance. A completely $\mathrm{N}$ - and O-desulfated, $\mathrm{N}$-reacetylated heparin (desulfated heparin) of comparable chain length also did not have any LTC-IC maintaining activity. Completely N- and O-desulfated, N-resulfated heparin, which is
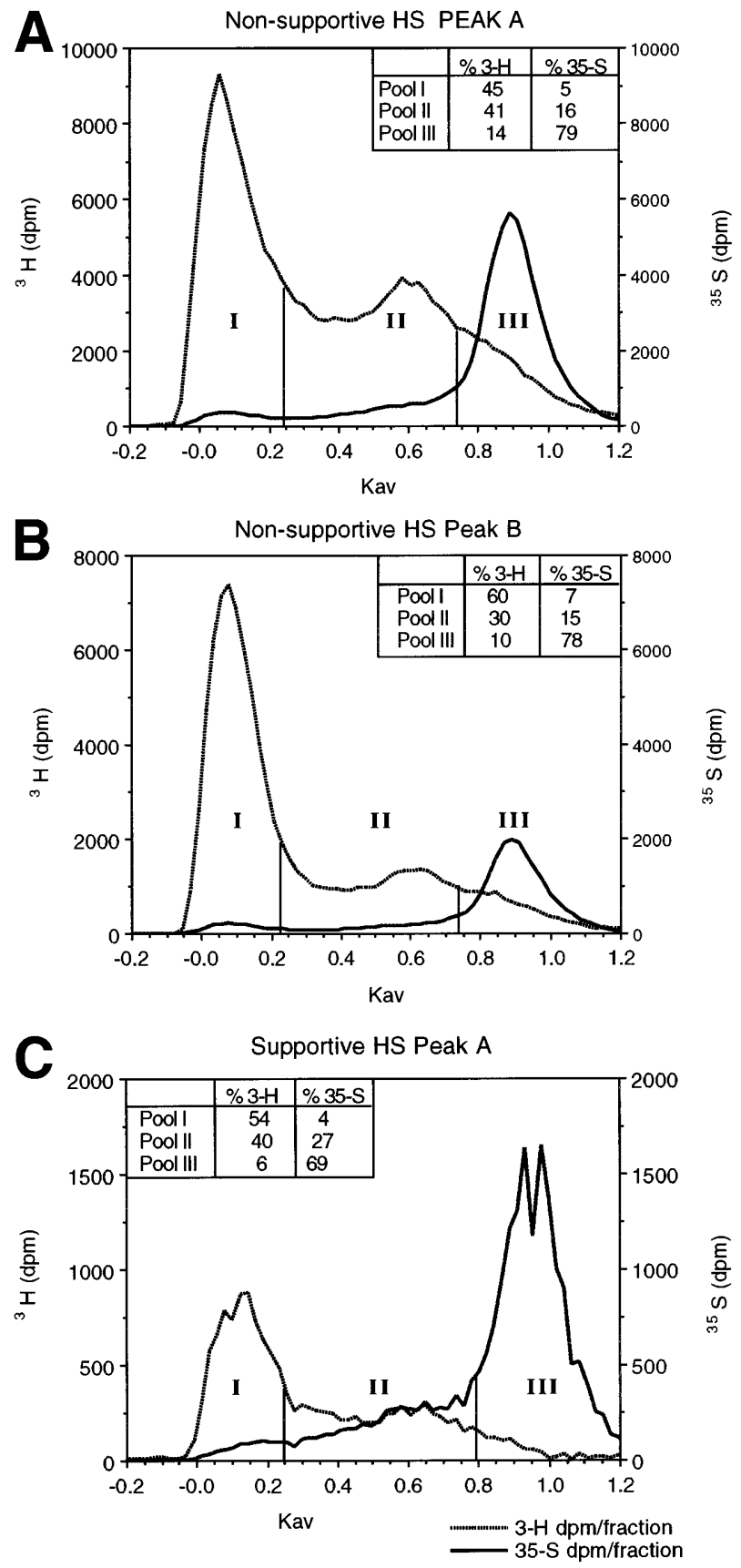

Fig 2. Gel filtration chromatography of HS oligosaccharides following nitrous acid digestion. HS in HPLC peaks A and B from the nonsupportive cell PG (A and $B$ ) and in peak $A$ from the supportive cell peak A PG (C) were subjected to low pH nitrous acid digestion and separated on a Sephadex G-25 column, as described in Materials and Methods. Fractions of $0.3 \mathrm{~mL}$ were collected and incorporated ${ }^{3} \mathrm{H}$ and ${ }^{35} \mathrm{~S}$ radioactivity was monitored.

largely depleted of 2-and 6-O-sulfate groups but retains N-sulfation (N-sulfated heparin), had only partial activity. In contrast, a combination of cytokines with $\mathrm{N}$-desulfated, N-reacetylated heparin, which retains 2- and 6-O-sulfate but not $\mathrm{N}$-sulfate groups (O-sulfated heparin), maintained LTC-IC to the same extent as unfractionated stromal SN or HS from the supportive 

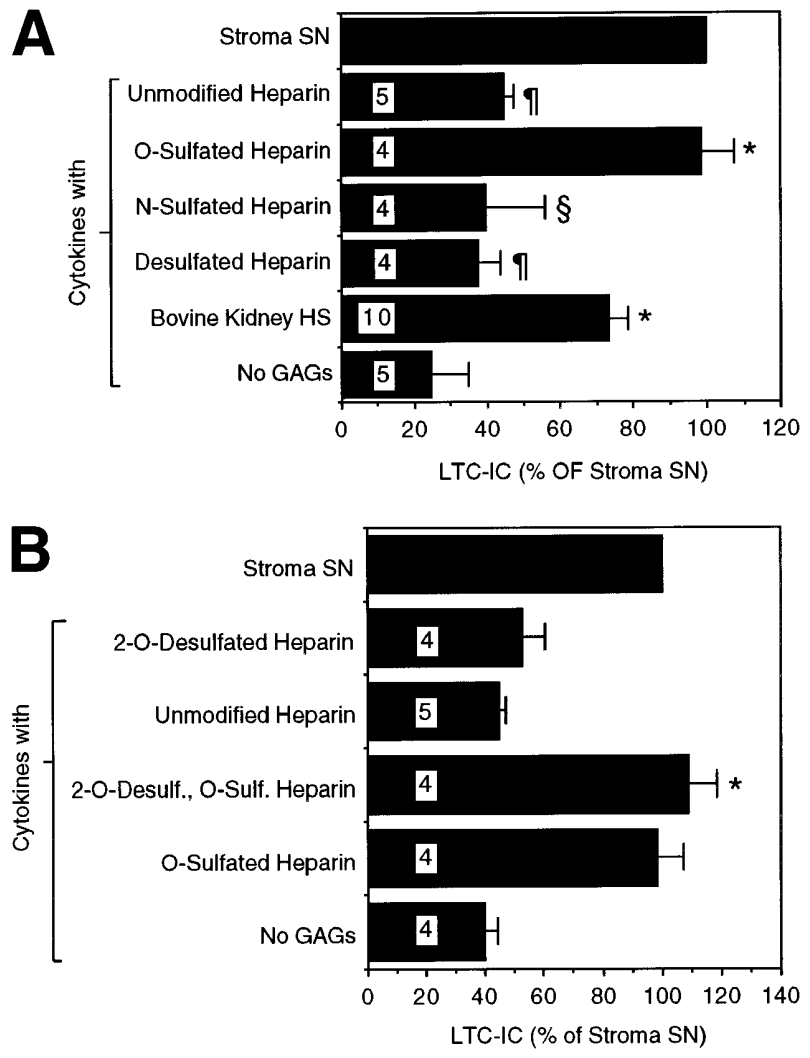

Fig 3. LTC-IC supportive activity of differentially sulfated glycosaminoglycans. A total of 10,000 to $17,000 \mathrm{DR}^{-}$cells were plated in 0.4- $\mu \mathrm{m}$ transwell inserts in 24-well tissue culture clusters. Cultures were maintained by daily replacement of the medium in the lower chambers of the wells by either stroma supematant (Stroma SN) or by LTBMC medium supplemented with a combination of cytokines $(500 \mathrm{pg} / \mathrm{mL}$ G-CSF, $50 \mathrm{pg} / \mathrm{mL}$ GM-CSF, $200 \mathrm{pg} / \mathrm{mL} \mathrm{SCF}, 50 \mathrm{pg} / \mathrm{mL}$ LIF, 2 $\mathrm{ng} / \mathrm{mL}$ IL-6, and $200 \mathrm{pg} / \mathrm{mL}$ MIP-1 $\alpha$ ) with or without $5 \mu \mathrm{g} / \mathrm{mL}$ of the indicated GAGs. Cultures were harvested after 5 weeks and cells were replated at limiting dilutions for estimation of LTC-IC frequency. The absolute number of LTC-IC in the starting cell population at day 0 was $0.40 \pm 0.07$ per $100 \mathrm{DR}^{-}$cells plated. The absolute number of LTC-IC after 5 weeks of culture in stroma SN was $0.21 \pm 0.04$ per 100 DR- cells initially plated at day 0 ( $52 \%$ of day 0 LTC-IC). Numbers within bars indicate number of experiments. (A) Comparison between cytokines only (No GAGs) and other conditions: $* P<.002$. Comparison between O-sulfated heparin and other conditions: $\S P<$ .02, $\mid P<.002$. (B) LTC-IC supportive activity of 2-0-desulfated glycosaminoglycans, prepared from unmodified heparin or from O-sulfated heparin as described in Materials and Methods. Comparison between cytokines only (No GAGs) and 2-0-desulfated O-sulfated heparin: $* P<.002$.

cells. Highly 6-O-sulfated bovine kidney HS maintained $70 \%$ to $80 \%$ LTC-IC. The optimal concentration of bovine kidney HS for support of LTC-IC maintenance was in the range of $5 \mu \mathrm{g} / \mathrm{mL}$, because higher $(20 \mu \mathrm{g} / \mathrm{mL})$ or lower $(1 \mu \mathrm{g} / \mathrm{mL})$ concentrations were less effective (data not shown). In contrast to their effects on LTC-IC maintenance, the addition of PGs from the two cells, chemically desulfated heparins, or bovine kidney HS to cytokines did not change the number of colonyforming cells (CFCs) or mature cells generated over 5 weeks compared with cultures using cytokines alone (data not shown).

To examine if 2-O-sulfation was required for the LTC-IC maintaining activity of the GAGs, unmodified heparin and the
O-sulfated heparin were subjected to 2-O-desulfation. ${ }^{49}$ LTC-IC maintaining capability of the O-sulfated heparin was not reduced by removal of the 2-O-sulfate groups (Fig 3B). These results suggest that 6-O-sulfation of GAGs is essential for supporting the maintenance of primitive hematopoietic progenitors and suggest further that $\mathrm{N}$-sulfation may be detrimental to this activity.

\section{O-Sulfated HS Selectively Bind Early-Acting Cytokines and ECM Components and Directly Mediate Adhesion of $\mathrm{CD} 34^{+}$Cells}

We then examined if these GAGs might contribute to the colocalization of primitive progenitors with early-acting cytokines and matrix components, thereby facilitating the formation of an appropriate microenvironmental niche. Affinity coelectrophoresis experiments demonstrated that supportive ${ }^{35} \mathrm{~S}$-labeled HS bound to IL-3, MIP- $1 \alpha$, PF4, TSP, and bFGF. In contrast, nonsupportive ${ }^{35} \mathrm{~S}$-labeled HS bound only PF4 and bFGF but not IL-3, MIP-1 $\alpha$, or TSP (Fig 4A). Neither HS bound to FN.

We calculated the maximal retardation of HS migration through PF4 as the retardation of the most avidly binding component of HS (which is represented by the uppermost end of the peak/smear). The retardation coefficient ${ }^{52}$ was calculated as follows: $\mathrm{R}=\left(\mathrm{M}_{0}-\mathrm{M}\right) / \mathrm{M}_{0}$, where $\mathrm{M}_{0}$ was the mobility of free heparin (taken as mobility in presence of ovalbumin [OVA]) and $\mathrm{M}$ was the mobility of heparin through a protein containing lane (PF4). Mobility was measured as the distance from the loading well at the top of the gel to the upper end of the HS smear. Thus, in presence of $4 \mu \mathrm{mol} / \mathrm{L}$ PF4: maximal $\mathrm{R}=0.58$ for the supportive $\mathrm{HS}$, and maximal $\mathrm{R}=0.36$ for the nonsupportive HS. Because retardation is a function of the binding affinity of the HS to the protein, these results indicate that a subgroup of the supportive HS binds with greater affinity to PF4 than the nonsupportive HS. In contrast, the nonsupportive HS were more homogenous in regard to PF4 binding and did not possess a comparable subset of HS that bound PF4 with high affinity.

To further confirm this binding, additional experiments were performed using the ${ }^{125}$ I-labeled HS from the two cells. As shown in Fig 4B, a component of the supportive HS, but not the nonsupportive HS, bound to TSP in a dose-dependent manner. Similarly, the ${ }^{125}$ I-labeled supportive HS but not the nonsupportive HS bound the cytokine MIP- $1 \alpha$ in a dose-dependent manner, between 10 and $250 \mathrm{nmol} / \mathrm{L} \mathrm{MIP}-1 \alpha$ (not shown). Thus, differences in the ability of HS from the two cell lines to support LTC-IC correlate with the ability of the HS to bind cytokines and ECM components that are important for support of primitive hematopoietic progenitors.

PF4 is active in maintaining LTC-IC, ${ }^{12}$ and its localization in the microenvironment is dependent on avid binding to GAGs. To examine if a high degree of O-sulfation, as is present in supportive HS but not in nonsupportive HS, may be responsible for localization of PF4, we tested the PF4 binding affinities of chemically desulfated heparins. Because the differentially sulfated heparins were not radiolabeled, binding was examined using surface plasmon resonance. As shown in Fig 5, the O-sulfated heparin and bovine kidney HS (which has a high degree of 6-O-sulfation) ${ }^{39}$ bound to PF4 with high affinity $\left(\mathrm{K}_{\mathrm{D}}\right.$ $4.26 \times 10^{-8} \mathrm{~mol} / \mathrm{L}$ and $4.0 \times 10^{-7} \mathrm{~mol} / \mathrm{L}$, respectively), 

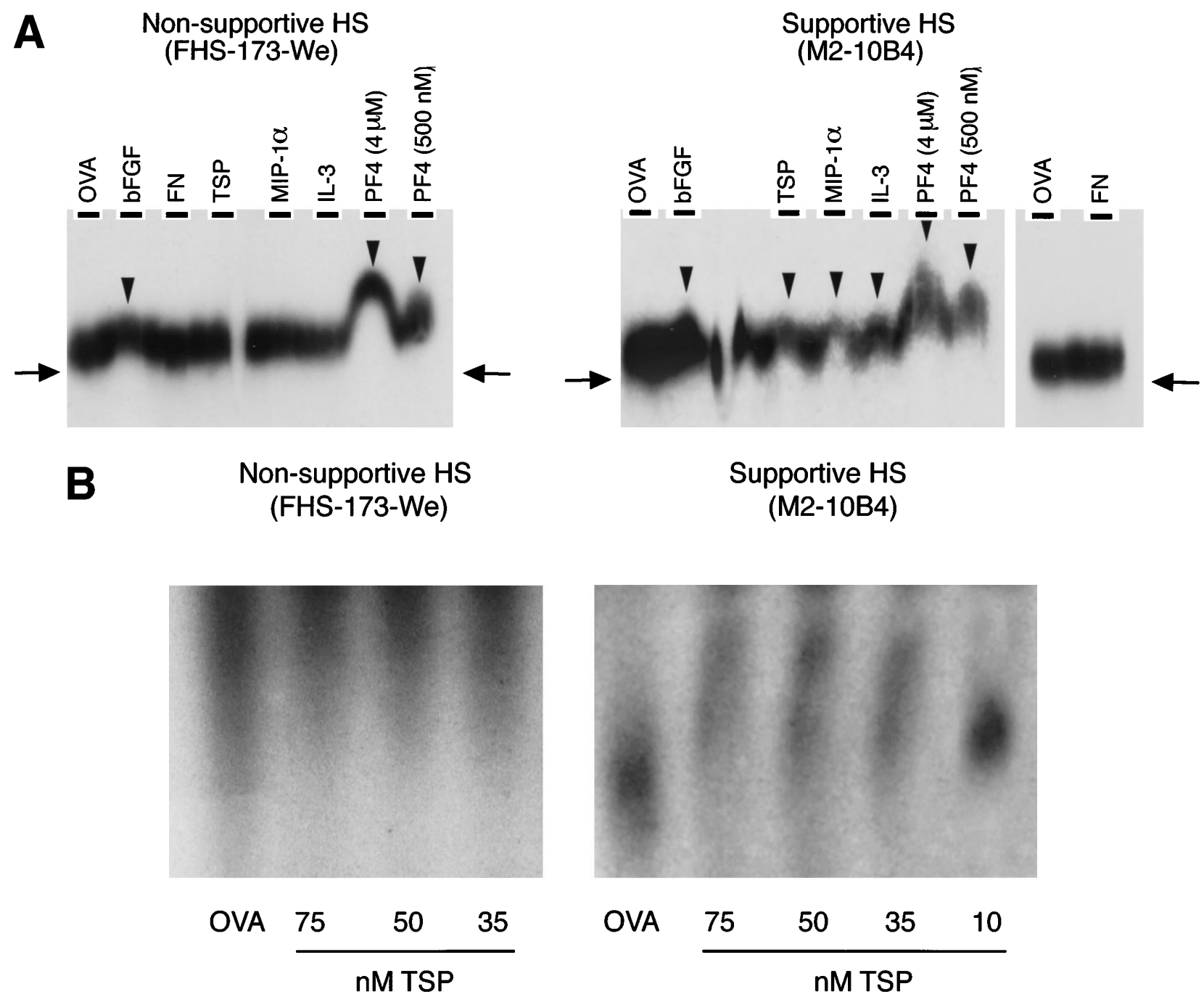

Fig 4. (A) Binding of ${ }^{35} \mathrm{~S}$-labeled HS to cytokines and matrix components. Binding was examined by affinity coelectrophoresis, as described in Materials and Methods. Proteins cast in the lanes were $500 \mathrm{nmol} / \mathrm{L}$ ovalbumin (OVA), $25 \mathrm{nmol} / \mathrm{L}$ bFGF, $275 \mathrm{nmol} / \mathrm{L} \mathrm{FN,} 100 \mathrm{nmol} / \mathrm{L}$ TSP, 500 $\mathrm{nmol} / \mathrm{L}$ MIP-1 $\alpha, 275 \mathrm{nmol} / \mathrm{L}$ IL-3, and PF4 (at the indicated concentrations). HS (40,000 to 50,000 dpm 35 Ser gel) from supportive and nonsupportive cells were electrophoresed into the protein-containing gels. The right-side panel in the autoradiograph for the supportive HS shows lack of binding to OVA and FN. ${ }^{35} \mathrm{~S}$ radioactivity was detected by autoradiography. The arrows indicate the extent of migration of unbound HS. The arrowheads indicate retardation of migration of HS due to binding to proteins in the gel. (B) Binding of 125 -HS to TSP. ${ }^{225}$-labeled HS $\left(10,000 \mathrm{cpm}{ }^{125}\right.$ I per lane) from the two cells was electrophoresed through ovalbumin (OVA; $\left.500 \mathrm{nmol} / \mathrm{L}\right)$ or the indicated concentrations of TSP. The migration of a component of the supportive HS was retarded by binding to TSP in a dose-dependent manner, compared with migration through ovalbumin. No binding was seen for the nonsupportive HS.

$\mathrm{N}$-sulfated heparin bound with significantly lower affinity $\left(\mathrm{K}_{\mathrm{D}}\right.$ $1.11 \times 10^{-6} \mathrm{~mol} / \mathrm{L}$ ), and completely desulfated heparin failed to demonstrate any detectable binding. The affinity of O-sulfated heparin was comparable to that of unmodified heparin $\left(\mathrm{K}_{\mathrm{D}} 4.16 \times 10^{-8} \mathrm{M}\right.$; see also Maccarana and Lindahl $\left.{ }^{57}\right)$, which contains a high degree of both $\mathrm{O}$ - and $\mathrm{N}$-sulfation of the GAG chains. These results suggest that $\mathrm{O}$-sulfation of heparin is necessary and sufficient for binding of PF4 and that $\mathrm{N}$-sulfation of GlcN may not significantly affect PF4 binding under these conditions. Although binding affinity of heparin to PF4 increases with increasing size of the heparin, ${ }^{57}$ differences in size are not likely to explain differences in binding of the modified heparins, because all preparations have similar average $\mathrm{M}_{\mathrm{r}}$.

Lastly, we examined if progenitors adhere directly to these
GAGs. Direct adhesion of FACS-purified human BM CD34 ${ }^{+}$ cells to ovalbumin-conjugated, differentially sulfated purified heparins was evaluated in the complete absence of stromal cells or other adhesive ligands. Sixteen percent to $18 \%$ of $\mathrm{CD}_{3} 4^{+}$ cells adhered to completely desulfated heparin or to N-sulfated heparin and $21 \% \pm 2 \%$ to unmodified heparin (Fig 6A). In contrast, a significantly higher proportion $(29 \% \pm 3 \% ; \mathrm{n}=8)$ of $\mathrm{CD}_{3} 4^{+}$cells adhered to O-sulfated heparin $(P<.002 v$ desulfated heparin, $P<.005 v \mathrm{~N}$-sulfated heparin, and $P<$ $.05 v$ unmodified heparin; $\mathrm{n}=9$ for each type of heparin). These results indicate that immobilized O-sulfated GAGs directly mediate the adhesion of human $\mathrm{CD} 34^{+}$cells. Using ${ }^{125}$ I-labeled HS from the two cells, we also observed that the supportive HS bound consistently to $\mathrm{CD} 34^{+}$cells in suspension (Fig 6B). The 


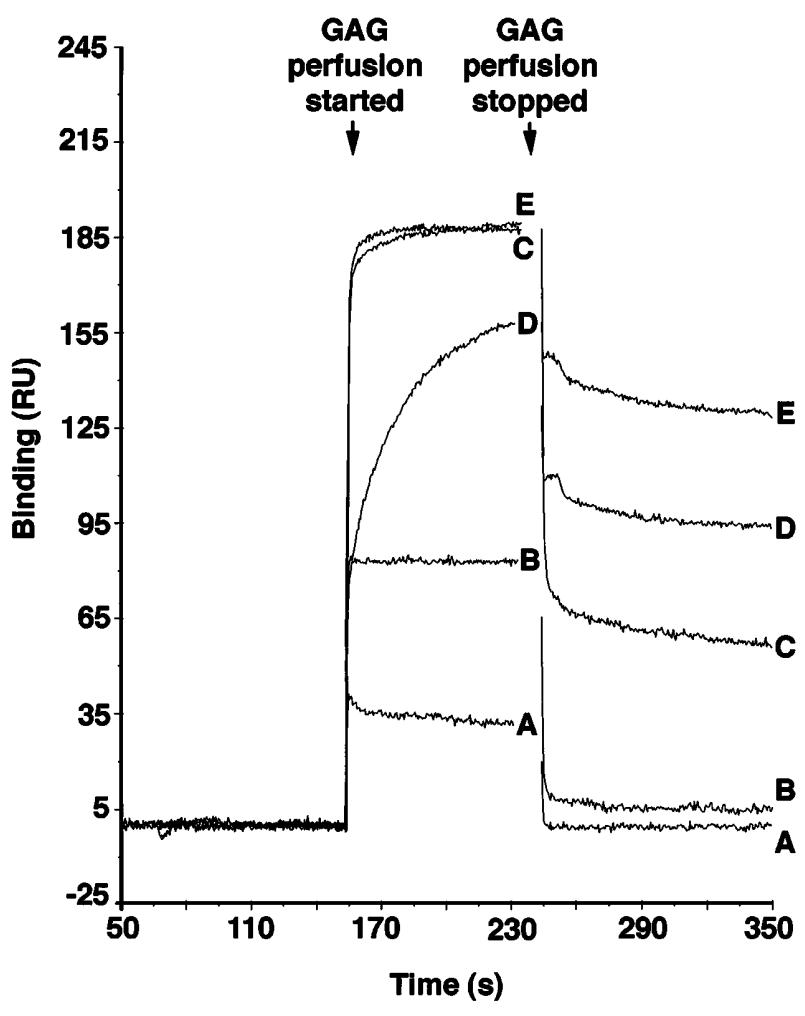

Fig 5. Binding of differentially sulfated GAGs to PF4. GAGs were perfused over biotinylated PF4 immobilized on a streptavidin chip in BIAcore biosensor equipment. Binding was measured in resonance units $\left(1 \mathrm{RU}=1 \mathrm{pg} / \mathrm{mm}^{2}\right)$ using surface plasmon resonance. Binding of each GAG was measured in triplicate at each concentration for five different concentrations. Representative binding curves are shown for the following concentrations of GAGs: (A) desulfated heparin, $3.4 \times 10^{-6} \mathrm{~mol} / \mathrm{L}$; (B) N-sulfated heparin, $3.4 \times 10^{-6} \mathrm{~mol} / \mathrm{L}$; (C) O-sulfated heparin, $1.7 \times 10^{-6} \mathrm{~mol} / \mathrm{L}$; (D) bovine kidney heparan sulfate, $8.33 \times 10^{-7} \mathrm{~mol} / \mathrm{L}$; and (E) unmodified heparin, $8.33 \times 10^{-7}$ mol/L.

binding of the nonsupportive HS was variable. These binding studies with cell line-derived HS complement the adhesion data with differentially sulfated heparins.

\section{DISCUSSION}

We demonstrate that the addition of the hematopoiesissupportive cell-derived PGs but not the nonsupportive cell derived PGs increases LTC-IC maintenance significantly. Compared with nonsupportive HS, the supportive HS that are responsible for this effect are larger and are more highly sulfated, specifically on the 6-O-position of GlcN located adjacent to modified regions having $\mathrm{GlcNSO}_{3}$. HS possessing these characteristics bind both ECM components and cytokines important for growth of primitive hematopoietic progenitors and mediate the direct adhesion of $\mathrm{CD}_{3} 4^{+}$cells to HS. Therefore, HSPGs with large, highly 6-O-sulfated HS side chains may be central components of the human hematopoietic stem cell niche in which conservation, proliferation, and differentiation of primitive progenitors is regulated. This conclusion is supported by a number of observations.

Firstly, the requirement of 6-O-sulfation of GAG for LTC-IC maintenance was demonstrated directly by studies examining the ability of differentially sulfated, purified heparins to support LTC-IC. Heparin and HS share important structural attributes, including the composition of disaccharide units and a high degree of sulfation. However, compared with HS, heparin contains a significantly higher proportion of the trisulfated disaccharide [-IdoA $\left(2-\mathrm{OSO}_{3}\right)-\mathrm{GlcNSO}_{3}\left(6-\mathrm{OSO}_{3}\right)$-] sequences and consequently is more $\mathrm{N}$-sulfated. ${ }^{33}$ After chemical $\mathrm{N}$-desulfation and $\mathrm{N}$-re-acetylation (O-sulfated heparin), these disaccharides retain 2-O-and 6-O-sulfation and are therefore highly enriched in repeating disaccharide units of [-IdoA $\left(2-\mathrm{OSO}_{3}\right)$-GlcNAc(6-OSO $\left.{ }_{3}\right)$-]. After 2-O-desulfation of the $\mathrm{O}$-sulfated heparin, the major sulfate residues remaining on the

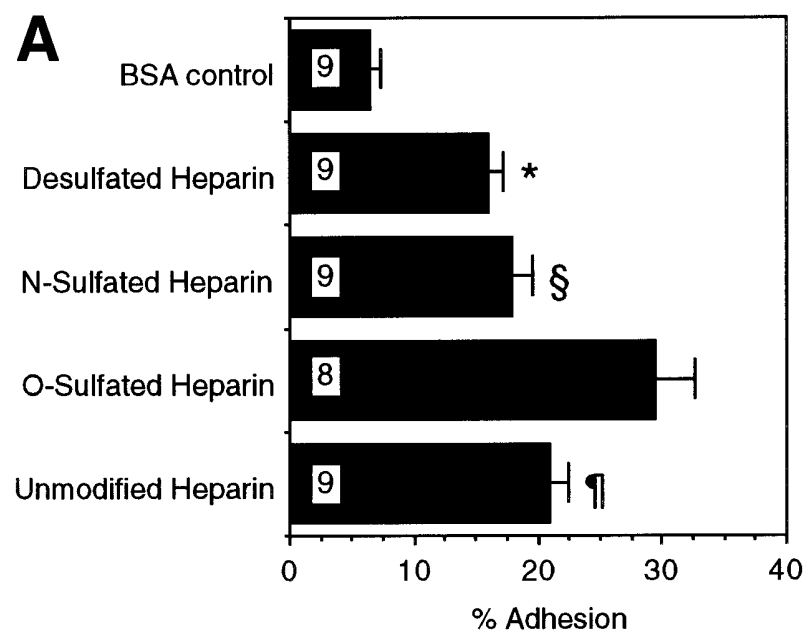

B

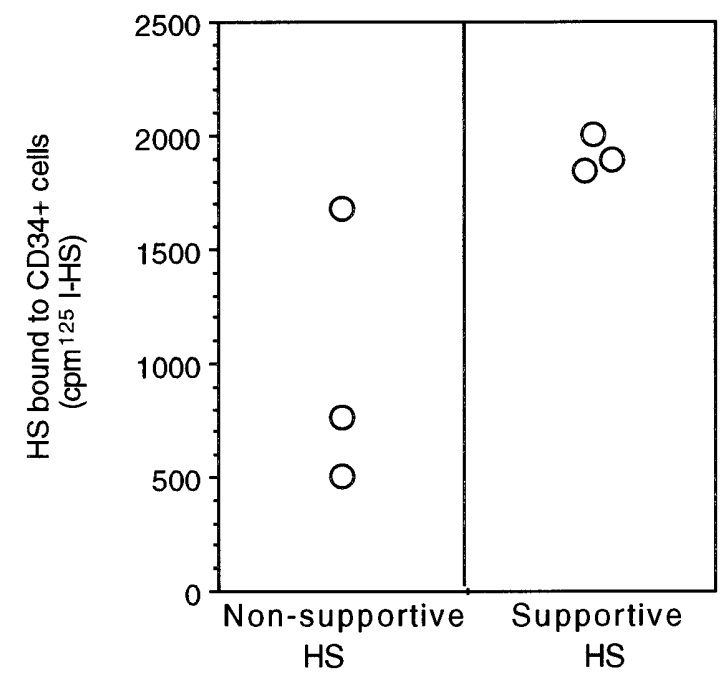

Fig 6. (A) Adhesion of CD34+ cells to differentially sulfated GAGs. ${ }^{51} \mathrm{Cr}$-labeled CD34 ${ }^{+}$cells $(20,000$ cells/ well) were incubated for 4 hours at $37^{\circ} \mathrm{C}$ in $48-w e l l$ plates previously coated with $5 \%$ BSA or with 100 $\mu \mathrm{g} / \mathrm{mL}$ ovalbumin-conjugated GAGs. The percentage of adhesion was calculated from the proportion of input cpm present in the adherent cells. Numbers within bars indicate the number of experiments. Comparison between 0-sulfated heparin and other conditions: $* \boldsymbol{P}<.002 ; \S P<.005 ; \uparrow P<.05$. (B) Binding of 125 I-HS to CD34 ${ }^{+}$ cells. The binding of $10^{6} \mathrm{cpm}$ of ${ }^{125}$-HS from the two cells to $0.75 \times 10^{6}$ CD34 $^{+}$cells suspended in $0.5 \mathrm{~mL}$ medium was estimated, as described in Materials and Methods. Radioactivity bound to the cells was counted using a gamma counter. 
heparin are as 6-O-sulfate. LTC-IC maintenance in the presence of this heparin possessing only 6-O-sulfate (2-O-desulfated, O-sulfated heparin) was equivalent to that seen with unfractionated stromal $\mathrm{SN}$ or in the presence of the supportive cell PG.

Secondly, like the supportive HS, bovine kidney HS maintained a large proportion of LTC-IC. Bovine kidney HS contains a high proportion of 6-O-sulfated GlcN but an extremely small proportion $(0.3 \%)$ of $2-\mathrm{O}$-sulfated GlcA. ${ }^{39}$

Thirdly, the capability of unmodified heparin, which has a high degree of both $\mathrm{N}$ - and O-sulfation, to support LTC-IC maintenance was significantly lower than heparin from which $\mathrm{N}$-sulfate groups had been removed (O-sulfated heparin). The LTC-IC supportive capability of N-sulfated heparin that lacks $\mathrm{O}$-sulfated groups was no better than that of completely $\mathrm{N}$ - and O-desulfated heparin or cytokines alone. This suggests that the presence of a high degree of $\mathrm{N}$-sulfation may interfere with the capability of O-sulfated GAGs to support LTC-IC maintenance. In agreement with this observation, the nonsupportive HS that are unable to support LTC-IC had less O-sulfation than supportive HS.

Fourthly, the ability of O-sulfated GAG or the supportive HS to enhance primitive progenitor maintenance correlates with their ability to colocalize $\mathrm{CD} 34^{+}$progenitors with cytokines and ECM components with known activity in early hematopoiesis. Previous studies indicate that GAGs contribute to cellstroma adhesive interactions ${ }^{22-25}$ by showing that target cell adhesion to multimolecular ECM or to stromal cells can be inhibited by soluble heparin or HS or by removal of HS from the stromal layer. However, it is possible that additional ECM or cell surface adhesive ligands or cytokines ${ }^{58-60}$ contribute to the observed adhesion. To demonstrate a direct role of structurally defined GAGs in progenitor adhesion, we determined adhesion of $\mathrm{CD} 34^{+}$cells to chemically desulfated heparins conjugated to ovalbumin and coated on cell culture plates in the absence of stromal cells or other ECM components. Adhesion of CD34 ${ }^{+}$ cells was highest to the $\mathrm{O}$-sulfated GAG and significantly less to desulfated or N-sulfated heparins. Furthermore, HS from the supportive cells directly bound to $\mathrm{CD} 34^{+}$cells in suspension. We also show that supportive HS, but not the nonsupportive HS, directly bound to a number of cytokines and ECM components important in early hematopoiesis, including IL-3, MIP- $1 \alpha$, and TSP. Whether specific GAG sequences are required for binding IL-3, MIP- $1 \alpha$, or TSP is not known. The supportive HS, which are larger and possess a high content of 6-O-GlcN, bind all three of these proteins with significantly greater avidity than the smaller, less 6-O-sulfated nonsupportive HS.

IL-3 and MIP- $1 \alpha$ are particularly critical for regulation of hematopoiesis, ${ }^{61}$ because the ex vivo survival of primitive human hematopoietic progenitors with myeloid and lymphoid differentiation potential depends on the presence of IL-3 and MIP- $1 \alpha$, but not on other early-acting cytokines that do not bind GAGs. ${ }^{11,62,63}$ We have previously shown that IL-3 and MIP-1 $\alpha$ require $\mathrm{O}$-sulfated GAGs for their LTC-IC maintaining activity (LTC-IC maintenance $32 \% \pm 2 \%$ with IL-3 + MIP- $1 \alpha$ and $95 \% \pm 7 \%$ with O-sulfated heparin + IL-3 + MIP-1 $\alpha) .{ }^{64}$ Also, we have demonstrated that PGs and MIP- $1 \alpha$ secreted by stromal cells are both sequestered on the microporous membranes of Transwells, on which primitive progenitors can be maintained in the absence of contact with stromal cells. ${ }^{17}$
Likewise, previous studies have shown that stromal HSPGs not only bind and present IL-3 in a biologically active form to hematopoietic cells, but may increase its mitogenic activity. 4,5,65 These studies, together with our observation that purified supportive HS directly bind IL-3 and MIP-1 $\alpha$, support the hypothesis that these HS may mediate colocalization of progenitors with functionally active cytokines.

The supportive HS also bound the ECM macromolecule TSP in a dose-dependent manner. Specific HS are essential for the localization of TSP in the ECM in vitro ${ }^{66}$ and in vivo, ${ }^{67}$ for the interaction of TSP with cell surfaces,${ }^{68}$ and for TSP + growth factor-mediated modulation of proliferation of diverse cells, including hematopoietic progenitors. ${ }^{69}$ Additionally, HS increases the capacity of cytokines and TSP to localize hematopoietic progenitors by adhesion. ${ }^{70}$ Therefore, the capability of the supportive HS but not the nonsupportive HS to bind TSP along with cytokines may be an important characteristic of the activity of HS on primitive hematopoietic progenitors.

The sulfation pattern described here for supportive HS is not unique, but may be present in variable proportions in HS from different sources. ${ }^{39}$ Several cell lines from human and nonhuman sources support the growth of human hematopoietic progenitors. ${ }^{6,8} \mathrm{HS}$ from one additional cell line that actively supports human LTC-IC have sulfation patterns and relatively longer HS chains, similar to HS from the supportive cells (P.G., unpublished observations). Thus, HS with relatively long (but not unusually so) chains and common short-block motifs, but with a higher extent of 6-O-sulfation, may be part of the minimal structural requirements for supporting primitive hematopoietic progenitors. Aside from the presence of specific sulfate groups, the organization of domains within the supportive cell HS may be an additional important determinant of its biologic activity. ${ }^{33,71}$ Current studies are further examining the structural characteristics of HS from the two cells.

These results in the hematopoietic system lead us to propose a role for specific HSPGs in the orchestration of local microenvironmental niches. In this model (Fig 7), HSPGs are responsible for the juxtaposition of target cells (hematopoietic progenitors in the present study) with microenvironmental cells, cytokines, and ECM proteins. These HSPGs may be expressed

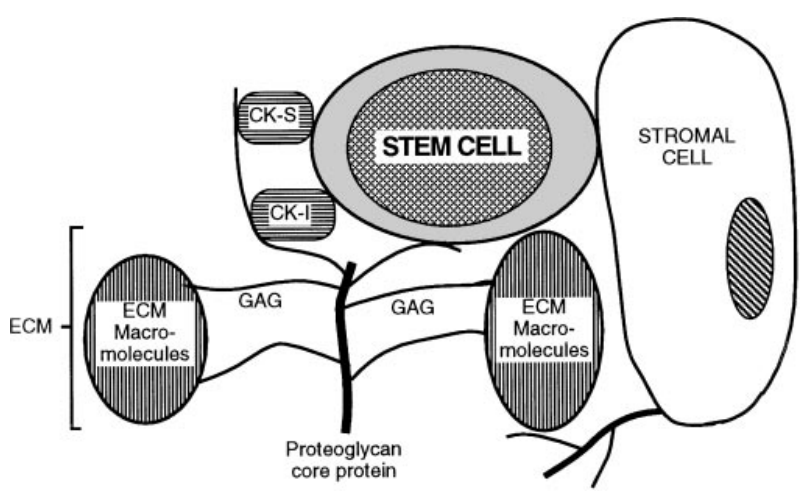

Fig 7. Model for proteoglycan-mediated juxtaposition of stem cells, cytokines, and ECM components. CK-S, growth stimulatory cytokines; CK-I, growth/cell cycle inhibitory cytokines and chemokines; ECM, extracellular matrix; GAG, glycosaminoglycan. See detailed discussion in the text. 
on stromal cells (eg, glypican, syndecans) or deposited as ECM (eg, perlecan). The PGs bind, sequester and present to the target cell growth-promoting (eg, IL-3 and bFGF) and growthinhibitory (eg, MIP-1 $\alpha$ and PF4) cytokines produced locally or by distant accessory cells. In addition, the same PGs bind ECM components (eg, TSP). To successfully organize a target cell niche, HS may require distinct structural characteristics that allow concomitant binding of the specific cytokines and ECM components in multimolecular cytokine/matrix/PG complexes. Thus, the structural diversity of HSPGs that results in the selective colocalization of cytokines and ECM components may lead to formation of discrete niches that induce target cell quiescence and survival and other niches that promote target cell proliferation or terminal differentiation. Our observation that the supportive cell HS is required for LTC-IC maintenance but not for differentiation of $\mathrm{CD} 34^{+}$cells into $\mathrm{CFCs}$ and mature blood cells further supports this notion.

\section{ACKNOWLEDGMENT}

The authors acknowledge the excellent technical assistance of Laurel Deloria and Brad Anderson and thank Dr James D. San Antonio (Jefferson Medical College, Philadelphia, PA) for helpful discussions.

\section{REFERENCES}

1. Lowry PA, Deacon D, Whitefield P, McGrath HE, Quesenberry PJ: Stem cell factor induction of in vitro murine hematopoietic colony formation by "subliminal" cytokine combinations: the role of "anchor factors." Blood 80:663, 1992

2. Keating A, Gordon MY: Hierarchical organization of hematopoietic microenvironments: Role of proteoglycans. Leukemia 2:766, 1988

3. Williams DA: Ex vivo expansion of hematopoietic stem and progenitor cells-Robbing Peter to pay Paul? Blood 81:3169, 1993

4. Roberts R, Gallagher J, Spooncer E, Allen TD, Bloomfield F, Dexter RM: Heparan sulphate bound growth factors: A mechanism for stromal cell mediated haemopoiesis. Nature 332:376, 1988

5. Gordon MY, Riley GP, Watt SM, Greaves MF: Compartmentalization of a haematopoietic growth factor (GM-CSF) by glycosaminoglycans in the bone marrow microenvironment. Nature 326:403, 1987

6. Deryugina EI, Müller-Sieburg CE: Stromal cells in long-term cultures: Keys to the elucidation of hematopoietic development? Crit Rev Immunol 13:115, 1993

7. Hangoc G, Daub R, Maze RG, Falkenburg JH, Broxmeyer HE, Harrington MA: Regulation of myelopoiesis by murine fibroblastic and adipogenic cell lines. Exp Hematol 21:502, 1993

8. Moore KA, Pytowski B, Witte L, Hicklin D, Lemischka IR: Hematopoietic activity of a stromal cell transmembrane protein containing epidermal growth factor-like repeat motifs. Proc Natl Acad Sci USA 94:4011, 1997

9. Verfaillie CM: Direct contact between human primitive hematopoietic progenitors and bone marrow stroma is not required for long-term in vitro hematopoiesis. Blood 79:2821, 1992

10. Verfaillie CM: Soluble factor(s) produced by human bone marrow stroma increase cytokine-induced proliferation and maturation of primitive hematopoietic progenitors while preventing their terminal differentiation. Blood 82:2045, 1993

11. Verfaillie CM, Catanzarro PM, Li W: Macrophage inflammatory protein- $1 \alpha$, interleukin 3 and diffusible marrow stromal factors maintain human hematopoietic stem cells for at least eight weeks in vitro. J Exp Med 179:643, 1994

12. Bhatia R, McGlave PB, Miller JS, Wissink S, Lin W-N, Verfaillie CM: A clinically suitable ex vivo expansion culture system for LTC-IC and CFC using stroma-conditioned medium. Exp Hematol 25:980, 1997
13. Burroughs J, Gupta P, Blazar BR, Verfaillie CM: Diffusible factors from the murine cell line M2-10B4 support human in vitro hematopoiesis. Exp Hematol 22:1095, 1994

14. Guba SC, Sartor CI, Gottschalk LR, Ye-Hu J, Mulligan T, Emerson SG: Bone marrow stromal fibroblasts secrete interleukin- 6 and granulocyte-macrophage colony-stimulating factor in the absence of inflammatory stimulation: Demonstration by serum-free bioassay, enzyme-linked immunosorbent assay and reverse transcriptase polymerase chain reaction. Blood 80:1190, 1992

15. Migliaccio AR, Migliaccio G, Johnson G, Adamson JW, TorokStorb B: Comparative analysis of hematopoietic growth factors released by stromal cells from normal donors or transplanted patients. Blood 75:305, 1990

16. Mielcarek M, Roecklein BA, Torok-Storb B: CD14 ${ }^{+}$cells in granulocyte colony-stimulating factor (G-CSF)-mobilized peripheral blood mononuclear cells induce secretion of interleukin-6 and G-CSF by marrow stroma. Blood 87:574, 1996

17. Gupta P, McCarthy JB, Verfaillie CM: Stromal fibroblast heparan sulfate is required for cytokine-mediated ex vivo maintenance of human long-term culture-initiating cells. Blood 87:3229, 1996

18. Wight TN, Kinsella MG, Keating A, Singer JW: Proteoglycans in human long-term bone marrow cultures: Biochemical and ultrastructural analyses. Blood 67:1333, 1986

19. Morris AJ, Turnbull JE, Riley GP, Gordon MY, Gallagher JT: Production of heparan sulphate proteoglycans by human bone marrow stromal cells. J Cell Sci 99:149, 1991

20. Gallagher JT, Spooncer E, Dexter TM: Role of the cellular matrix in haemopoiesis I: Synthesis of glycosaminoglycans by mouse bone marrow cell cultures. J Cell Sci 63:155, 1983

21. Siczkowski M, Robertson D, Gordon MY: Synthesis and deposition of glycosaminoglycans in the murine hemopoietic stromal line S17: Modulators of the hemopoietic microenvironment. Exp Hematol 20: 1285, 1992

22. Wight TN, Kinsella MG, Qwarnström EE: The role of proteoglycans in cell adhesion, migration and proliferation. Curr Opin Cell Biol 4:793, 1992

23. Coombe DR, Watt SM, Parish CR: Mac-1 (CD11b/CD18) and CD45 mediate the adhesion of hematopoietic progenitor cells to stromal cell elements via recognition of stromal heparan sulfate. Blood 84:739, 1994

24. Gordon MY, Riley GP, Clarke D: Heparan sulfate is necessary for adhesive interactions between human early hemopoietic progenitor cells and the extracellular matrix of the marrow microenvironment. Leukemia 2:804, 1988

25. Siczkowski M, Clarke D, Gordon MY: Binding of primitive hematopoietic progenitor cells to marrow stromal cells involves heparan sulfate. Blood 80:912, 1992

26. Mason IJ: The ins and outs of fibroblast growth factors. Cell 78:547, 1994

27. Lyon M, Deakin JA, Mizuno K, Nakamura T, Gallagher JT: Interaction of hepatocyte growth factor with heparan sulfate. Elucidation of the major heparan sulfate structural determinants. J Biol Chem 269:11216, 1994

28. David G: Integral membrane heparan sulfate proteoglycans. FASEB J 7:1023, 1993

29. Lindahl U, Lidholt K, Spillmann D, Kjellén L: More to "Heparin" than anticoagulation. Thromb Res 75:1, 1994

30. Ruoslahti E: Structure and biology of proteoglycans. Annu Rev Cell Biol 4:229, 1988

31. San Antonio JD, Lander AD, Karnovsky MJ, Slayter HS: Mapping the heparin-binding sites on type I collagen monomers and fibrils. J Cell Biol 1125:1179, 1994

32. Gallagher JT, Lyon M, Steward WP: Structure and function of heparan sulfate proteoglycans. Biochem J 236:313, 1986 
33. Salmivirta M, Lidholt K, Lindahl U: Heparan sulfate: A piece of information. FASEB J 10:1270, 1996

34. Faham S, Hileman RE, Fromm JR, Linhardt RJ, Rees DC: Heparin structure and interactions with basic fibroblast growth factor. Science 271:1116, 1996

35. Ornitz DM, Herr AB, Nilsson M, Westman J, Svahn C-M, Waksman G: FGF binding and FGF receptor activation by synthetic heparan-derived di- and trisaccharides. Science 268:432, 1995

36. Fedarko NS, Conrad HE: A unique heparan sulfate in the nuclei of hepatocytes: Structural changes with the growth state of the cells. J Cell Biol 102:587, 1986

37. Castellot JJ, Choay J, Lormeau JC, Peitton M, Sache E, Karnovsky MJ: Structural determinants of the capacity of heparin to inhibit the proliferation of vascular smooth muscle cells. II Evidence for a pentasaccharide sequence that contains a 3-O-sulfated group. J Cell Biol 102:1979, 1986

38. Platt JL, Trescony P, Lindman B, Oegema TR: Heparin and heparan sulfate delimit nephron formation in fetal metanephric kidneys. Dev Biol 139:338, 1990

39. Maccarana M, Sakura Y, Tawada A, Yoshida K, Lindahl U: Domain structure of heparan sulfates from bovine organs. J Biol Chem 271:17804, 1996

40. Verfaillie CM, Blakolmer K, McGlave P: Purified primitive human hematopoietic progenitor cells with long-term in vitro repopulating capacity adhere selectively to irradiated bone marrow stroma. J Exp Med 172:509, 1990

41. Berenson RJ, Andrews RG, Bensinger WI, Kalamasz D, Knitter G, Buckner CD, Bernstein ID: Antigen CD34+ marrow cells engraft lethally irradiated baboons. J Clin Invest 81:951, 1988

42. Taswell C: Limiting dilution assays for the determination of immunocompetent cell frequencies: I: Data analysis. J Immunol 126: 1614,1981

43. Brown DM, Michael AF, Oegema TR: Glycosaminoglycan synthesis by glomeruli in vivo and in vitro. Biochim Biophys Acta 674:96, 1981

44. Conrad GW, Hamilton C, Haynes E: Differences in glycosaminoglycans synthesized by fibroblast-like cells from chick cornea, heart and skin. J Biol Chem 252:6861, 1977

45. Heinegard D, Hascall VC: Characterization of chondroitin sulfate isolated from trypsin-chymotrypsin digests of cartilage proteoglycans. Arch Biochem Biophys 165:427, 1974

46. Wasteson A: A method for the determination of the molecular weight and molecular weight distribution of chondroitin sulfate. J Chromatogr 59:87, 1971

47. Trescony PV, Oegema TR, Farnam BJ, Deloria LB: Analysis of heparan sulfate from the Engelbreth-Holm-Swarm (EHS) tumor. Connect Tissue Res 19:219, 1989

48. Midura RJ, Salustri A, Calabro A, Yanagishita M, Hascall VC: High-resolution separation of disaccharide and oligosaccharide alditols from chondroitin sulphate, dermatan sulphate and hyaluronan using CarboPac PA1 chromatography. Glycobiology 4:333, 1994

49. Jaseja M, Rej RN, Sauriol F, Perlin AS: Novel regio- and stereoselective modifications of heparin in alkaline solution: Nuclear magnetic resonance spectroscopic evidence. Can J Chem 67:1449, 1989

50. Lee KB, al-Hakim A, Loganathan D, Linhardt RJ: A new method for sequencing linear oligosaccharides on gels using charged, fluorescent conjugates. Carbohydr Res 214:155, 1991

51. San Antonio JD, Slover J, Lawler J, Karnovsky MJ, Lander AD: Specificity in the interactions of extracellular matrix proteins with subpopulations of the glycosaminoglycan heparin. Biochemistry 32 : 4746, 1993

52. Lee MK, Lander AD: Analysis of affinity and structural selectivity in the binding of proteins to glycosaminoglycans: Development of a sensitive electrophoretic approach. Proc Natl Acad Sci USA 88:2768, 1991
53. Mach H, Volkin DB, Burke CJ, Linhardt R, Fromm JR, Loganathan D, Mattsson L: Nature of the interaction of heparin with acidic fibroblast growth factor. Biochemistry 32:5480, 1993

54. Fisher RJ, Fivash M: Surface plasmon resonance based methods for measuring the kinetics and binding affinities of biomolecular interactions. Curr Opin Biotechnol 5:389, 1994

55. Danishefsky I, Tzeng F, Ahrens M, Klein S: Synthesis of heparin-sepharoses and their binding with thrombin and antithrombinheparin cofactor. Thromb Res 8:131, 1976

56. Sanderson PN, Nieduszynski IA, Huckerby TN: Very-high-field nmr studies of bovine lung heparan sulfate oligosaccharides produced by nitrous acid deaminative cleavage. Biochem J 211:677, 1983

57. Maccarana M, Lindahl U: Mode of interaction between platelet factor 4 and heparin. Glycobiology 3:271, 1993

58. San Antonio JD, Lander AD, Wright TC, Karnovsky MJ: Heparin inhibits the attachment and growth of Balb/c-3T3 fibroblasts on collagen substrata. J Cell Physiol 150:8, 1992

59. Tanaka Y, Adams DH, Hubscher S, Hirano H, Siebenlist U, Shaw $\mathrm{S}$ : T-cell adhesion induced by proteoglycan-immobilized cytokine MIP-1ß. Nature 361:79, 1993

60. Migas J, Hurley RW, Verfaillie CM: MIP- $1 \alpha$ and TGF- $\beta$ increase adhesion of normal committed progenitors to marrow stroma. Exp Hematol 22:736, 1994 (abstr)

61. Broxmeyer HE, Sherry B, Cooper S, Lu L, Maze R, Beckman MP, Cerami A, Ralph P: Comparative analysis of the human macrophage inflammatory protein family of cytokines (chemokines) on proliferation of human myeloid progenitor cells: Interacting effects involving suppression, synergistic suppression, and blocking of suppression. J Immunol 150:3448, 1993

62. Leary AG, Zeng HQ, Clark SC, Ogawa M: Growth factor requirements for survival in $\mathrm{G}_{0}$ and entry into the cell cycle of primitive human hematopoietic progenitors. Proc Natl Acad Sci USA 89:4013, 1992

63. Miller JS, Verfaillie CM: Ex vivo culture of CD34+Lin-DRcells in stroma derived soluble factors, MIP- $1 \alpha$ and IL-3 maintains not only myeloid but also lymphoid progenitors in a novel switch culture assay. Blood 84:419a, 1994 (abstr, suppl 1)

64. Gupta P, Dudek AZ, Slungaard A, Oegema TR, Verfaillie CM: $\mathrm{O}$-sulfated heparan sulfate glycosaminoglycans are required to support long-term ex vivo maintenance of human LTC-IC. Blood 88:186a, 1996 (abstr, suppl 1)

65. Alvarez-Silva M, Borojevic R: GM-CSF and IL-3 activities in schistosomal liver granulomas are controlled by stroma-associated heparan sulfate proteoglycans. J Leukoc Biol 59:435, 1996

66. Schon P, Vischer P, Volker W, Schmidt A, Faber V: Cellassociated proteoheparan sulfate mediates binding and uptake of thrombospondin in cultured porcine vascular endothelial cells. Eur J Cell Biol 59:329, 1992

67. Corless CL, Mendoza A, Collins T, Lawler J: Colocalization of thrombospondin and syndecan during murine development. Dev Dyn 193:346, 1992

68. Sun X, Kaesberg PR, Choay J, Harenberg J, Ershler WB, Mosher DF: Effects of sized heparin oligosaccharides on the interactions of Chinese hamster ovary cells with thrombospondin. Semin Thromb Hemost 18:243, 1992

69. Long MW, Briddell R, Walter AW, Bruno E, Hoffman R: Human hematopoietic stem cell adherence to cytokines and matrix molecules. J Clin Invest 90:251, 1992

70. Bruno E, Luikart SD, Long MW, Hoffman R: Marrow-derived heparan sulfate proteoglycan mediates the adhesion of hematopoietic progenitor cells to cytokines. Exp Hematol 23:1212, 1995

71. Lortat-Jacob H, Turnbull JE, Grimaud J-A: Molecular organization of the interferon $\gamma$-binding domain in heparan sulphate. Biochem $\mathrm{J}$ 310:497, 1995 